\title{
TINDAK PIDANA KORUPSI DALAM PERSPEKTIF HUKUM PIDANA DAN HUKUM PIDANA ISLAM
}

\author{
Hilal Arya Ramadhan', Yusrizal ${ }^{2}$, Fauzah Nur Aksa² \\ ${ }^{1}$ Mahasiswa Fakultas Hukum Universitas Malikussaleh \\ ${ }^{2}$ Dosen Fakultas Hukum Universitas Malikussaleh
}

\begin{abstract}
Summons of witnesses at each level of criminal case examination has consequences for the cost of attending the summons. So far, the provisions regarding the cost of summoning witnesses and experts have been regulated in Article 229 of the Criminal Procedure Code and Law Number 13 of 2006 concerning Protection of Witnesses and Victims and Law Number 2 of 2002 concerning Procedures for Protection of Witnesses and Victims in Human rights violations, however, in reality the fees that have been regulated in the law are not fully provided to all witnesses and even if there are costs they are not up to standard and not optimal. These costs include accommodation costs, consumption costs, transportation costs and costs of reimbursing lost income due to having to attend calls. The purpose of this research is to find out and explain the compensation mechanism to witnesses or experts in order to differentiate information in the criminal justice system in the jurisdiction of the Takengon District Court and what are the obstacles in reimbursing costs to witnesses or experts in order to provide information in the criminal justice system in the region. the law of the Takengon District Court. This type of research is juridical empirical, that is, approaching the problem through legal research by looking at the prevailing legal norms and relating them to the facts that exist in society in connection with the problems encountered in the research. The results showed that the cost reimbursement mechanism for witnesses or experts in order to provide information at the police level, namely starting with budget proposals, the Central Aceh Police proposed a budget through an index on other operational items. The index is available only for very difficult and difficult cases while there is no index for easy cases. The reason for this is the limited budget in the police index. Reimbursement for witnesses or experts at the prosecutor's level did not work properly, because the budget included in the Prosecutor's DIPA was inadequate, such as for consumption, transportation and accommodation costs. So that often the prosecutor's office bears the cost. Reimbursement for witnesses or experts at court. level was never given because the authorities to summon and examine witnesses were the police and the prosecutor's office. The court is only tasked with adjudicating criminal cases. Constraints for reimbursement of fees to witnesses or experts in the context of providing information in the criminal justice system in the jurisdiction of the Takengon District Court, namely the limited police budget, inadequate budget at the prosecutor's office, no further regulation regarding how much fees should be paid to witnesses. It is hoped that law enforcement officials should implement and submit budgets in the Police index and in the DIPA of the Attorney General's Office and the application of witness rights can be further enhanced and maximized, in order to guarantee the protection of witnesses' rights. The government also needs to provide a balance regarding reimbursement of expenses to witnesses in order to achieve a sense of justice in the implementation at every level of the criminal case examination process, because basically a witness has the right to receive reimbursement in accordance with Article 229 of the Criminal Procedure Code and the Law. Number 13 of 2006 concerning Protection of Witnesses and Victims.
\end{abstract}

Keywords: Reimbursement, Witness or Expert, Criminal Justice System 


\section{PENDAHULUAN}

Tindak pidana korupsi merupakan fenomena yang sangat memprihatinkan dalam kehidupan masyarakat dan bangsa Indonesia pada beberapa dekade terakhir ini. Korupsi telah menempatkan Indonesia pada jajaran negara terkorup di dunia. Dampak buruk yang dihasilkan oleh tindak pidana korupsi ini sangat membahayakan bagi kehidupan manusia.

Tindak pidana korupsi adalah tingkah laku yang menyimpang dari tugas-tugas resmi sebuah jabatan negara karena keuntungan status atau uang yang menyangkut pribadi (perorangan, keluarga dekat, kelompok sendiri) atau melanggar aturan-aturan pelaksanaan beberapa tingkah laku pribadi. Korupsi merupakan perbuatan yang sangat merugikan keuangan negara dan masyarakat sehingga dapat menghambat jalannya pembangunan nasional, oleh karena itu perlu dikikis habis.

Tindak pidana korupsi merupakan kejahatan luar biasa (extraordinary crime) yang merusak dan mengancam sendi-sendi kehidupan bangsa. Tanpa disadari, korupsi sebenarnya telah merusak segala bidang, tidak hanya merusak pada bidang eksekutif dan yudikatif serta legislatif saja, namun korupsi juga telah merambah ke lingkungan masyarakat pada umumnya.

Adapun menurut Undang-Undang Republik Indonesia Nomor 31 Tahun 1999 Tentang Pemberantasan Tindak Pidana Korupsi yang dimaksud dengan korupsi ialah perbuatan melawan hukum melakukan perbuatan memperkaya diri sendiri atau orang lain atau suatu korporasi yang dapat merugikan keuangan negara atau perekonomian negara.

Hukum pidana di Indonesia memandang tindak pidana korupsi sebagai masalah besar yang belum dapat diselesaikan dengan tuntas oleh bangsa ini. Salah satu agenda reformasi adalah pemberantasan korupsi yang sudah mengakar dan menjadi virus dalam tubuh bangsa Indonesia. Segala upaya untuk memberantas korupsi sudah dilakukan baik oleh pemerintah Orde Baru, sampai dengan masa Susilo Bambang Yudhoyono. Namun hasilnya bukan malah berkurang, justru korupsi semakin menjadi-jadi.

Negara Indonesia adalah negara yang berdasarkan pada Ketuhanan Yang Maha Esa. Selain sistem hukum pidana umum negara ini juga tidak terlepas dari sistem hukum islam, dimana mayoritas penduduk di Indonesia adalah beragama islam. Oleh karena itu sangatlah naïf apabila mengesampingkan ajaran agama sebagai sebuah solusi untuk menyadarkan pelaku koruptor sekaligus memberantas akar penyakit korupsi. Dalam Islam perilaku korupsi secara tegas telah dilarang, sebagaimana Hadist Nabi Muhammad Shallallahu 'Alaihi wa Sallam yang diriwayatkan oleh Ibnu Abbas, Rasulullah Shallallahu "Alaihi wa Sallam bersabda "Tidak akan masuk surga tubuh yang diberi makan dengan yang haram.” Berkaitan dengan itu juga terdapat Firman Allah Subhanahu wa ta'al didalam Al-Quran surah Al-Baqarah ayat 18

Artinya : Dan janganlah sebahagian kamu memakan harta sebahagian yang lain di antara kamu dengan jalan yang bathil dan (janganlah) kamu membawa (urusan) harta itu kepada hakim, supaya kamu dapat memakan sebahagian daripada harta benda orang lain itu dengan (jalan berbuat) dosa, padahal kamu mengetahui.

Pokok permasalahan yang dikaji pada ayat di atas adalah larangan dalam memakan harta orang lain yang bukan haknya secara umum, dengan cara bathil. Termasuk di dalamnya tindakan kejahatan korupsi yang dilakukan oleh koruptor. Namun jika dikaitkan dengan upaya pemberantasan korupsi di Indonesia, Larangan korupsi sesungguhnya telah banyak dijelaskan dan terkandung dalam sumber hukum Islam. Cukup banyak ayat Al Qur'an dan Hadits yang 
mengandung penjelasan tentang berbagai larangan mengenai korupsi yang termasuk sebagai tindak pengkhianatan dan kezaliman.

Sekalipun telah banyak upaya yang dilakukan oleh pemerintah dan agama pun jelas telah melarang korupsi, namun korupsi di Indonesia tetap saja meningkat, baik dari segi kuantitas kasus yang terjadi dan kualitas tindak pidana korupsi yang dilakukan pelaku pun cenderung semakin sistematis, semakin meluas.

\section{METODE PENELITIAN}

Metode penelitian hukum adalah suatu proses untuk menemukan aturan hukum, prinsipprinsip hukum, maupun doktrin-doktrin hukum guna menjawab isu hukum yang dihadapi. Metode penelitian hukum merupakan cara kerja ilmuan yang salah satunya ditandai dengan penggunaan metode. Secara harfiah metode diartikan sebagai suatu jalan yang harus ditempuh menjadi penyelidikan atau penelitian berlangsung menurut suatu rencana tertentu. Metode penelitian hukum merupakan suatu cara yang sistematis dalam melakukan sebuah penelitian.

\section{PEMBAHASAN}

\section{Pangaturan Hukum Pidana Mengenai Tindak Pidana Korupsi}

Ditinjau dari sudut Bahasa kata korupsi bisa berarti kemerosotan dari yang semua baik, sehat dan benar menjadi penyelewengan, buruk. Kemudian arti kata korupsi yang disimpulkan oleh Poerwodarminto dalam Kamus Besar Bahasa Indonesia bahwa korupsi merupakan perbuatan yang buruk, seperti penggelapan uang, penerimaan uang sogok, dan sebagainya. $\mathrm{H}$. A. Brasz mendefinisikan korupsi dalam pengertian sosiologis sebagai: "penggunaan yang korup dari kekuasaan yang dialihkan, atau sebagai penggunaan secara diam-diam kekuasaan yang dialihkan berdasarkan wewenang yang melekat pada kekuasaan itu atau berdasarkan kemampuan formal, dengan merugikan tujuan-tujuan kekuasaan asli dan denga menguntungkan orang luar atas dalil menggunakan kekuasaan itu dengan sah".

Tindak pidana korupsi merupakan objek hukum yang pada konteks Indonesia dikategorikan sebagai salah satu delik khusus di luar KUHP dan pada saat ini telah diatur dalam Undang-Undang Nomor 20 Tahun 2001, Tentang Perubahan Atas Undang-Undang Nomor 31 Tahun 1999, Tentang Pemberantasan Tindak Pidana Korupsi. Dalam pasal ini dijelaskan bahwa korupsi adalah: "setiap orang yang dengan tujuan menguntungkan diri sendiri atau orang lain atau suatu korporasi, menyalahgunakan kewenangan, kesempatan atau sarana yang ada padanya karena jabatan atau kedudukan yang dapat merugikan keuangan negara atau perekonomian negara".

Soedjono Dirjosisworo mengkritisi ketentuan-ketentuan Tindak Pidana Korupsi dalam KUHP tersebut ternyata kurang efektif dalam menanggulangi korupsi, sehingga dirasakan perlu adanya peraturan yang dapat lebih memberi keleluasaan kepada penguasa untuk bertindak terhadap pelaku-pelakunya.

Ketentuan-ketentuan tindak pidana korupsi yang terdapat dalam KUHP dirasa kurang efektif dalam mengantisipasi atau bahkan mengatasi permasalahan tindak pidana korupsi. Oleh karena itu, dibentuklah suatu peraturan perundang-undangan guna memberantas masalah korupsi, dengan harapan dapat mengisis serta menyempurnakan kekurangan yang terdapat pada KUHP. Dengan berlakunya Undang-Undang 20 Tahun 2001 tentang Perubahan atas Undang- 
Undang Nomor 31 Tahun 1991 tentang Pemberantasan tindak Pidana korupsi, maka ketentuan Pasal 209 KUHP, Pasal 210 KUHP, Pasal 387 KUHP, Pasal 388 KUHP, Pasal 415, Pasal 416.

Perumusan tindak pidana korupsi menurut pasal 2 ayat 1 Undang-Undang Nomor 20 Tahun 2001 adalah setiap orang (orang-perorangan atau korporasi) yang memenuhi unsur/elemen dari pasal tersebut. Dengan demikian, pelaku tindak pidana korupsi menurut pasal ini adalah "Setiap Orang", tidak ada keharusan Pegawai Negeri. Jadi, juga dapat dilakukan oleh orang yang tidak berstatus sebagai pegawai negeri atau korporasi, yang dapat berbentuk badan hukum atau perkumpulan.

Secara substansi Undang-Undang Nomor 20 Tahun 2001 telah mengatur berbagai aspek yang kiranya dapat menjerat berbagai modus operansi tindak pidana korupsi yang semakin rumit. Dalam Undang-Undang ini tindak pidana korupsi telah dirumuskan sebagai tindak pidana formil, pengertian pegawai negeri telah diperluas, pelaku korupsi tidak didefenisikan hanya kepada orang perorang tetapi juga pada korporasi, sanksi yang dipergunakan adalah sanksi minimum sampai pidana mati, seperti yang tercantum dalam pasal 2 dan pasal 3 Undang-Undang Nomor 20 Tahun 2001 tentang Pemberantasan Tindak Pidana Korupsi dan telah pula dilengkapi dengan pengaturan mengenai kewenangan penyidik, penuntut umumnya hingga hakim yang memeriksa di sidang pengadilan Tindak Pidana Korupsi.

Pengaturan tindak pidana korupsi dilakukan melalui kerja sama dengan dunia Internasioanal. Hal ini dilakukan dengan cara menandatangani konvensi PBB Pembuktian telah diterapkan pembuktian tebalik secara berimbang dan sebagai kontrol, Undang-Undang ini dilengkapi dengan Pasal 41 pengaturan mengenai peran serta masyarakat, kemudian dipertegas dengan dikeluarkannya Peraturan Pemerintah Nomor 71 Tahun 2000 tentang Tata Cara Pelaksanaan Peran Serta Masyarakat dan Pemberian Penghargaan dalam Pencegahan dan Pemberantasan tentang anti korupsi yang memberikan peluang untuk mengembalikan aset-aset para koruptor yang di bawa lari ke luar negeri. Dengan meratifikasi konvensi ini, Indonesia akan diuntungkan dengan penanda tangan konvensi ini. Salah satu yang penting dalam konvensi inia adalah adanya pengaturan tentang pembekuan, penyitaan dari harta benda hasil korupsi yang ada di luar negeri.

\section{Pangaturan Hukum Pidana Islam Mengenai Tindak Pidana Korupsi}

Islam memandang korupsi sebagai perbuatan keji. Perbuatan korupsi dalam konteks agama Islam sama dengan fasad, yakni perbuatan yang merusak tatanan. kehidupan yang pelakunya dikategorikan melakukan Jinayaat al-kubra (dosa besar).

Korupsi dalam Islam adalah perbuatan melanggar syariat. Syariat Islam bertujuan untuk mewujudkan kemaslahatan bagi umat manusia. Diantara kemaslahatan yang hendak dituju tersebut adalah terpeliharanya harta (hifdzul maal) dari berbagai bentuk pelanggaran dan penyelewengan, bahkan Islam mengatur dan menilai harta sejak perolehannya hingga pembelanjaannya, Islam memberikan tuntunan agar dalam memperoleh harta dilakukan dengan cara-cara yang bermoral dan sesuai dengan hukum Islam yaitu dengan tidak menipu, tidak memakan riba, tidak berkhianat, tidak menggelapkan barang milik orang lain, tidak mencuri, tidak curang dalam takaran dan timbangan, tidak korupsi, dan lain sebagainya.

Kata korupsi secara literer memang tidak ditemukan dalam khazanah Islam, tetapi substansi dan persamaannya bisa dicari dan ditelusuri dalam Islam. Abu Hapsin, memberikan pemahaman umum tentang korupsi sebagai suatu tindakan melanggar hukum dengan maksud memperkaya diri sendiri, orang lain atau korporasi yang berakibat merugikan keuangan negara 
atau perekonomian negara. Bentuk-bentuk korupsi apabila ditinjau dari sisi syariat Islam dapat diklasifikasikan dengan bentuk ghulul (penggelapan), risywah (penyuapan), Sariqah, ghashab (mengambil paksa hak/harta orang lain), khianat, dan al-maks (pungutan liar).

1. Ghulul (Penggelapan)

Menurut etimologi, kata ghulul berasal dari kata kerja ghalala-yaghlilu, yang bermakna syiddat al'athsy wa harāratuhu (sangat kehausan dan kepanasan). Secara lebih spesifik dikemukakan dalam kamus Bahasa Arab "al-Mu'jam al-Wasīth" bahwa kata ghulul berasal dari kata kerja ghalla-yaghullu yang berarti khāna fi almaghnam wa ghairihi (berkhianat dalam pembagian harta rampasan perang atau dalam harta-harta lainnya). Dalam arti yang kedua ini, kata ghulul disebutkan oleh Allah Subhanahu wa ta'ala dalam Surah Āli Imrān Ayat 161:

Artinya : Tidak mungkin Nabi Muhammad SAW. berkhianat (dalam urusan harta rampasan perang). Barangsiapa berkhianat, niscaya pada hari kiamat ia akan datang membawa apa yang dikhianatkannya itu. Kemudian setiap orang akan diberi balasan tentang apa yang ia kerjakan dengan (balasan) setimpal, dan mereka tidak dizalimi.

Adapun definisi ghulul secara terminologis adalah mengambil sesuatu dan menyembunyikannya dalam hartanya.

2. Risywah (Penyuapan)

Menurut etimologis, kata risywah berasal dari Bahasa Arab dari kata yaitu rasya-yarsyu, dengan masdar dari kata risywah, rasywah, atau rusywah yang bermakna al-ju'l yaitu upah, hadiah, komisi atau suap. Tentang makna kata risywah, Ibnu Manzhur dalam bukunya "Lisanul Arab" mengemukakan penjelasan bahwa kata risywah terbentuk dari kalimat rasya al-farkh berarti 'anak burung merengek-rengek ketika mengangkat kepalanya kepada induknya untuk disuapi'.

Secara terminologis, risywah adalah sesuatu yang diberikan dalam rangka mewujudkan kemaslahatan atau sesuatu yang diberikan dalam rangka membenarkan yang batil/salah atau menyalahkan yang benar. Rasulullah Shallallahu 'Alaihi wa Sallam telah mengingatkan dalam sabdanya:

"Rasulullah shallallahu 'alaihi wasallam melaknat orang yang menyuap dan yang menerima suap.” H.R. Abu Daud .

\section{Sariqah}

Kata Sariqah merupakan bentuk fa'il dari kata saraqa yang secara etimologi bermakna mengambil barang milik orang lain dengan cara sembunyi-sembunyi dan tipu daya. Sedangkan secara terminologi, Sariqah adalah mengambil sejumlah harta senilai sepuluh dirham yang masih berlaku, disimpan di tempat penyimpanannya atau dijaga dan dilakukan oleh seorang mukallaf secara sembunyi-sembunyi serta tidak terdapat unsur syubhat sehingga bila barang tersebut kurang dari sepuluh dirham yang masih berlaku maka tidak dikategorikan sebagai pencurian.

4. Ghashab (Mengambil Paksa Hak/Harta Orang Lain)

Definisi Ghashab Secara etimologis, ghashab berasal dari kata kerja ghashaba-yaghshibughashban yang berarti akhadzahu qahran wa zulman (mengambil sesuatu secara paksa dan zalim). Secara lebih lengkap, Muhammad al-Khatib al-Syarbini menjelaskan definisi ghashab yaitu: akhdzu al-syai' zhulman wa qabla akhdzi zhulman jihāran (mengambil sesuatu secara zalim, sebelum mengambilnya secara zalim ia melakukannya juga secara terang-terangan). Semakna dengan definisi tersebut, Abdul Qahir al-Jurjani mendefinisikan ghashab yaitu akhdzu al-syai' zhulman mālan kāna aw ghairihi (mengambil sesuatu secara zalim, baik yang diambil 
itu harta atau yang lainnya). Demikian juga definisi yang sama diartikan menurut bahasa yaitu: "Ghashab adalah mengambil sesuatu dari tangan seseorang dengan jalan kekerasan (paksa)". Sedangkan secara terminologis, ghashab diartikan sebagai upaya untuk menguasai hak orang lain secara permusuhan/terang-terangan.

Adapun dalil tentang larangan melakukan ghashab terdapat dalam Al-Qur'ān Surah AnNisa' Ayat 29:

Artinya: Hai orang-orang yang beriman, janganlah kalian saling memakan harta sesama kalian dengan jalan yang batil, kecuali dengan jalan perniagaan yang berlaku dengan suka sama-suka di antara kalian. Dan janganlah kalian membunuh diri kalian; Sesungguhnya Allah Maha Penyayang kepada kalian.

5. Khiyanah (Khianat)

Khianat Kata khianat berasal dari Bahasa Arab yang merupakan bentuk kata kerja khānayakhūnu dengan masdar khawnan-khānatan-khiyānatan, dan mukhānatan yang berarti an yu 'tamana al-insān falā yanshah (sikap tidak becusnya seseorang pada saat diberikan kepercayaan). Adapun bentuk isim fā'il dari fi'il khāna-yakhūnu adalah khā in yang berarti alladzì khāna mā ja'ala 'alaihi amīnan (seseorang yang berkhianat terhadap sesuatu yang dipercayakan kepadanya). Semakna dengan definisi tersebut, Imam al-Syaukāni mendefinisikan khā 'in adalah man ya khudzu al-māl khafiyyatun wa yazhharu al-nushhu li al-mālik (orang yang mengambil harta secara sembunyi-sembunyi dan menampakkan perilaku baiknya terhadap pemilik harta tersebut).

Konteks korupsi di Indonesia, salah satu pangkal penyebabnya adalah khianat yang dilakukan oleh pejabat. Larangan khianat yang sudah disampaikan dalam Al-Qur'an ribuan tahun yang lalu sekarang terlah terbukti nyata. Bahwa khianat memang benar-benar menyebabkan banyak kerusakan. Pejabat berani korupsi, yang bukan pejabat berani ingkar janji, berbohong dan perbuatan tercela lainnya demi mendapatkan keuntungan duniawi. Oleh karenanya manusia dituntut untuk bersikap adil dan menjalankan amanah dalam pergaulan. Jika manusia bisa melaksanakannya, maka akan menjadikannya menjadi orang terhormat, baik dalam pandangan sang Pencipta maupun sesama manusia. Sebagaimana dalam Firman Allah Subhanahu wa ta'ala QS. Al-Ahzab: (72):

Artinya : Sesungguhnya Kami telah mengemukakan amanat kepada langit, bumi dan gununggunung, Maka semuanya enggan untuk memikul amanat itu dan mereka khawatir akan mengkhianatinya, dan dipikullah amanat itu oleh manusia. Sesungguhnya manusia itu Amat zalim dan Amat bodoh.

\section{Al-Maks (Pungutan Liar)}

Definisi Al-Maks, berasal dari kata al-maks adalah bentuk masdar atau invinitive dari kata kerja makasa-yamkisu yang berarti memungut cukai, menurunkan harga, dan menzalimi. Ibnu Manzur juga mengartikan kata al-maks dengan al-jibayah (cukai). Bahkan dengan lebih detail beliau mengemukakan al-Maks adalah sejumlah uang (dirham) yang diambil dari para pedagang di pasar-pasar pada zaman jahiliyah"

Semakna dengan definisi tersebut, Ahmad al-Siharanfuri juga mengutip definisi al-maks sebagaimana dalam kitab Al-Bidayah wa an-Nihayah yaitu al-Maks adalah cukai yang diambil pelaku, yaitu sebesar 1/10 (dari harta seluruhnya) dalam hal ini pada umumnya terdapat unsur kezaliman. Seorang penguasa akan masuk neraka karena kebijakannya mengarah kepada 
kezaliman tersebut, dan para pemungut 1/10 (dari seluruh harta pedagang) akan masuk neraka karena membantu penguasa dalam melaksanakan pemungutan dimaksud.

Dari uraian tentang beberapa pengertian al-maks di atas, dapat disimpulkan bahwa tradisi pungutan liar atau cukai ilegal sudah dikenal sejak masa permulaan lahirnya Islam.

\section{KESIMPULAN}

Pengaturan mengenai tindak pidana korupsi menurut hukum pidana telah jelas diatur dalam Undang-Undang Nomor 20 Tahun 2001 Perubahan Atas Undang-Undang 31 Tahun 1999 Tentang Pemberantasan Tindak Pidana Korupsi. Undang-Undang ini menjelaskan tindak pidana korupsi adalah "setiap orang yang dengan tujuan menguntungkan diri sendiri atau orang lain atau suatu korporasi, menyalahgunakan kewenangan, kesempatan atau sarana yang ada padanya karena jabatan atau kedudukan yang dapat merugikan keuangan negara atau perekonomian negara".

Pengaturan tindak pidana korupsi menurut hukum Islam secara literer memang tidak ditemukan dalam khaszanah Islam, tetapi substansi dan persamaannya bisa dicari dan ditelusuri. Adapun bentuk-bentuk korupsi apabila ditinjau dari sisi syariat Islam dapat diklasifikasikan dengan nama ghulul (penggelapan), risywah (penyuapan), Sariqah (pencurian), ghashab (mengambil paksa hak/harta orang lain), khianat, dan al-maks (pungutan liar) dan pengaturannya pun telah jelas diatur dalam Al Qur'an dan Hadist.

\section{Saran}

1. Pihak penegak hukum diharapkan lebih tegas dalam menangani permasalahan tindak pidana korupsi, apalagi dalam memberikan sanksi/hukuman untuk meminimalisir tindak pidana korupsi.

2. Merevisi kembali Undang-Undang tentang permberantasan korupsi dan kepada para penyusun Undang-Undang Tindak Pidana Korupsi agar lebih memperhatikan masalah sanksi kepada para koruptor sebaiknya menerapkan sanksi yang lebih tegas keras dan bisa memberikan efek jera kepada pelaku tindak pidana korupsi. Sanksi yang sangat tegas yang terdapat dalam Hukum Pidana Islam bisa menjadi pilihan untuk diadopsi ke dalam UndangUndang Tindak Pidana Korupsi.

\section{DAFTAR PUSTAKA}

Abu Fida' Abdur Rafi', 2006, Terapi Penyakit Korupsi, Republika, Jakarta.

Abdul Ghofur Anshori, dan Yulkarnanin Harahab, 2008, Hukum Islam Dinamika dan Perkembangannya di Indonesia, Total media, Jakarta.

Abdulkadir Muhammad, 2004, Hukum dan Penelitian Hukum, PT.Citra Aditya Bakti, Bandung. Abdullah Hehamahua, 2004, Membangun Gerakan Antikorupsi Dalam Perspektif Pengadilan, LP3 UMY, Yogyakarta.

Abdul Halim Hasan Binjai, 2006, Tafsir Ahkam, Kencana, Jakarta.

Ahmad Wardi Muslich, 2004, Pengantar dan Asas Hukum Pidana, Sinar Grafika, Jakarta.

Aliy Al-Sabuniy, 2004, Rawa'i al-Bayan: Tafsir Ayat al-Ahkam min al-Qur'an, Vol. I, Dar alKutub al-'Ilmiyyah, Beirut.

Al-Hikmah, 2013, Al-Qur'an Terjemahan, Departemen Agama RI, Jakarta. 
Al-Shadiq Abdurrahman al-Gharyani, 2004, Fatwa-Fatwa Muamalah Kontemporer, Pustaka Progresif, Surabaya.

Al-Siharanfuri, 2012, Badzlu al-Majhūd fi Halli Abì Dawud dalam M. Nurul Irfan, Korupsi dalam Hukum Pidana Islam, Amzah, Jakarta.

Andi Hamzah, 2006, Pemberantasan Korupsi Melalui Hukum Pidana Nasional dan Internasional, PT. Raja Grafindo Persada, Jakarta

Andi Hamzah, 2008, Asas-Asas Hukum Pidana (Edisi Revisi), Rineke Cipta, Jakarta

Andi Hamzah, 2010, Asas-asas Hukum Pidana, Rineka Cipta, Jakarta.

Buchari Said, 2015, Hukum Pidana Materil, Fakultas Hukum UNPAS, Bandung.

Barda Nawawi, 2008, Kebijakan Hukum Pidana, kencana, Semarang.

Chaerudin, dkk, 2008, Strategi Pencegahan dan Penegakan Hukum Tindak Pidana Korupsi, PT. Refika Aditama, Bandung.

Darwan Prinst, 2002, Pemberantasan Tindak Pidana Korupsi, Bandung.

Danial Zainal Abidin, 2008, Al-Qur'an For Life Excellence, Al-Hikmah, Jakarta.

Firman Wijaya, 2008, Peradilan Korupsi Teori dan Praktik, Penaku Maharini Press, Jakarta, 2008.

Frans Maramis, 2012, hukum pidana umum dan tertulis di Indonesia, PT Raja Grafindo Persada, Jakarta.

Fakultas Hukum Universitas Malikussaleh, 2015, Pedoman Pembelajaran Tugas Akhir, Lhokseumawe.

IGM Nurdjana, 2009, Sistem Hukum Pidana dan Bahaya Laten Korupsi (Problematik Sistem Hukum Pidana dan Implikasinya pada Penegakan Hukum Tindak Pidana Korupsi), Total Media, Yogyakarta.

I Made Widnyana, 2010, Asas-Asas Hukum Pidana, PT. Fikahati Aneska, Jakarta.

Komisi Pemberantasan Korupsi, 2009, Buku Panduan Kamu Buat Ngelawan Korupsi Pahami

Dulu Baru Lawan, KPK, Jakarta.

Kamri A, 2005, Pidana Mati dan Ham, tnp, Bandung.

Lilik Mulyadi. 2011, Tindak Pidana Korupsi di Indonesia; Normatif, Teoritis, Praktik dan Masalahnya. PT. Alumni. Bandung.

Moeljatno, 1980, Azas-azas Hukum Pidana, Gajah Mada University Press, Yogyakarta.

Moeljatno, 2008, Asas-Asas Hukum Pidana, Rineke Cipta, Jakarta.

Moeljatno, 1999, KUHP (Kitab Undang-undang Hukum Pidana), Cet. Ke-20, Bumi Aksara, Jakarta.

Muhammad Nurul Irfan, 2011, Korupsi dalam Hukum Pidana Islam, Amzah, Jakarta.

Neng Sarmida, dkk, 2002, Diktat Hukum Pidana, Bagian Hukum Pidana Universitas Andalas, Padang.

Mahmud Marzuki, 2011, Penelitian Hukum, Kencana Prenada Media Group, Jakarta.

Mahrus Ali, 2011, Dasar-dasar Hukum Pidana, Sinar Grafika, Jakarta.

Muhammad Sayyid Sabiq, 2011, Fiqih Sunnah 4, Pena Pundi Aksara, Jakarta.

Muhammadiyah, Nahdatul Ulama PartnershipKemitraan, 2010, Koruptor itu Kafir, Mizan, Jakarta.

Rahmat Hakim, 2000, Hukum Pidana Islam, Pustaka Setia, Bandung.

Robert Klitgaard, 2001, Membasmi Korupsi, Yayasan Obor Indonesia, Jakarta

S.R. Sianturi, 1996, Asas-asas Hukum Pidana di Indonesia dan Penerapannnya, Alumni Ahaem-Petehaem, Jakarta. 
Sabri Samin, 2008, Pidana Islam dalam Politik Hukum Indonesia, Kholam.

Setiawan Budi Utomo, 2003, Fiqih Aktual Jawaban Tuntas Masalah Kontemporer, Gema Press Insani, Jakarta.

Scott McClellan, 2009, Kebohongan di Gedung Putih: Warisan Dosa-dosa Bush bagi Penggantinya, Gramedia Pustaka Utama, Jakarta.

Sutherland and Cressey, 1974, The Control of Crime (terj. Sudjono), Tarsito, Bandung. Soedjono Dirdjosisworo, 2011, Masalah Perkembangan Tindak Pidana Korupsi di Indonesia, dalam Lilik Mulyadi, Tindak Pidana Korupsi di Indonesia. PT. Alumni. Bandung.

Syamsul Anwar, dkk. 2006, Fiqih Anti Korupsi: Perspektif Ulama Muhammadiyah, Majelis Tarjih dan Tajdid Muhammadiyah. Jakarta.

Surachmin \& Suhandi Cahaya, 2015, Strategi dan Teknik Korupsi: Mengetahui untuk Mencegah, Sinar Grafika, Jakarta.

S. H. Alatas, 1986, Sosiologi Korupsi Sebuah Penjelajahan Dengan Data Kontemporer, LP3ES, Jakarta.

Tri Andrisman, 2009, Hukum Pidana Asas-Asas Dan Aturan Umum Hukum Pidana Indonesia. Unila. Lampung.

W. J. S. Poerwodarmito, 1976, Kamus Umum Bahasa Indonesia, Balai Pustaka, Jakarta.

Arie Siswanto, 2009, Pidana Mati Dalam Perspektif Hukum Internasional, Jurnal Ilmu Hukum Refleksi Hukum Edisi April.

Idrus Alghiffary, 2017, Studi Komperatif Pemidanaan Tindak Pidana Korupsi Dalam Hukum Positif Dan Hukum Islam, dalam Jurnal edisi 1.

Musyafaullah, 2004, Muhamadiyah dalam Gerakan Anti Korupsi, dalam Narasi: Jurnal Penelitian Agama dan Sosial, Vol. V. 